\title{
An Eclectic Discussion of the Effects of COVID-19 Pandemic on the World Economy During the First Stage of the Spread
}

\author{
Stavros Kalogiannidis ${ }^{1}$, Fotios Chatzitheodoridis ${ }^{1} \&$ Stamatis Kontsas $^{2}$ \\ ${ }^{1}$ Department of Regional and Cross Border Development, University of Western Macedonia, Kozani, Greece \\ 2 Department of Business Administration, University of Western Macedonia, Kozani, Greece \\ Correspondence: Stavros Kalogiannidis, Department of Regional and Cross Border Development, University of \\ Western Macedonia, Kozani, Greece.
}

Received: August 10, 2020

Accepted: September 14, 2020

Online Published: November 30, 2020

doi:10.5430/ijfr.v11n6p137

URL: https://doi.org/10.5430/ijfr.v11n6p137

\begin{abstract}
This paper examines the economic impact of the COVID-19 pandemic, which, according to the World Health Organization, has affected every country and has caused millions of deaths as well as huge financial losses. This paper, then, explores recent statistics documenting the disruption of the world economy. Of course, the blow at the level of business, market, employment, income, industries, companies, and so on is an issue that should be constantly investigated. The ongoing impact study proposal is based on the fact that each developing country has taken measures and enacted policies to reduce the direct impact of COVID-19. However, as research shows, each country has different records and sizes of impacts to their economies, and any government effort to reduce these effects should take into account national losses and impacts so the recovery measures are proportionate. Government measures should be adapted to the operational needs and difficulties of the country to effectively ensure resilience, security, reduction of economic losses and sustainable industrialization.
\end{abstract}

Keywords: COVID-19, pandemic, impact, economy, business, industry, market

JEL codes: I10, I15, I18

\section{Introduction}

The coronavirus pandemic, which first appeared in China, has affected people in 188 countries worldwide. The spread of this virus, in addition to the millions of deaths it has caused, has affected many businesses around the world and the global economy in general. The economic cost of the pandemic seems to be enormous, and everyone is wondering how economic recovery can be achieved.

This article, therefore, will examine the economic impact of this pandemic worldwide with the ultimate goal of revealing precisely how the pandemic has affected the global economy.

The purpose of this paper is to make a first review on the effects of Covid 19 relates from the beginning and its distribution to economic and social aspects all over the world. This research focuses on the financial effects and more specifically on the decrease of production function level. Therefore analyzed the macroeconomic impacts such as unemployment level, entrepreneurship, consumption, growth rate. This paper also evaluated the governmental policies due to the pandemic crisis and the effects of these issues on Asia, Europe and United States of America. This pandemic is in progressive status and all these data which are including in our research are under monitoring for further research.

\section{The Economic Impact of the COVID-19 Pandemic}

\subsection{The Beginning of the Pandemic}

The manifestation of the coronavirus pandemic, SARS-COVID-19 of 2019-2020, is a complex of mysterious and suspected cases of pneumonia that first appeared in Yuhan, the capital of Hubei Province, China. The spread of the virus and hundreds of deaths quickly drew attention to a possible outbreak of the disease nationwide, causing similar concern to the Beijing National Health Committee (NHC), which began sending experts to Wuhan on December 28, 2019. On January 8, the new coronavirus was identified as the leading cause of the mysterious pneumonia (Khan, 2020), and an open access database was quickly published (Cohen, 2020).

The delayed and controversial responses of the Wuhan and Hubei authorities did not hold back the outbreak of 
criticism from the public and the media (Yuan, 2020). By January 29, 2020, the virus had spread to every Chinese province. Public health was deemed to be in a state of emergency. On January 31, the World Health Organization spoke of an outbreak of international health, and there were fears about the spread of the virus, given that China does not have a strong health care system. As of February 8, more than 724 deaths had been reported from pneumonia associated with the virus, with 34,878 confirmed cases. In Hubei alone, there were 24,953 cases of patient infection and 699 related deaths (Yella, 2020).

As early as the end of January, orders for epidemic controls began in every part of China: body temperature measurement for visitors to the country, suspension of bus and rail services, and the quarantine of cities in Hubei, and laws banning traffic were passed across the continent. There was a shortage of face masks with this protective material in short supply. Other countries helped China by donating medical supplies (Bloomberg, 2020).

China quickly took action, drawing praise from the World Health Organization (WHO, 2020a). Thus, where they had been counting thousands of deaths a day, now, with timely measures, they have been reduced to less than 100 per day throughout China. Of course, this phenomenon, which started in China, led to discrimination against the country by other governments in terms of censorship, with news agencies spreading that China deliberately exaggerated the extent of its citizens' deaths internationally (Hernández, 2020; Myers, 2020; Myers \& Rubin, 2020; Sobey, 2020).

Of course, the pandemic was not limited to the narrow geographical boundaries of China. COVID-19 quickly spread to other countries. The 2019-2020 coronavirus outbreak, caused by COVID-19, was declared a pandemic by the World Health Organization as it spread to every country in the world. The pandemic was declared on March 11, 2020 (WHO, 2020a). COVID-19 has been reported to have affected many countries in all six regions of the World Health Organization. The source of COVID-19 is the coronavirus SARS-CoV-2 (WHO, 2020b), which, after SARS-CoV and MERS-CoV, is the third zoonotic coronavirus. COVID-19 causes various diseases, such as severe acute respiratory syndrome (SARS), Middle East respiratory syndrome (MERS; WHO, 2015), and coronavirus disease 2019 (COVID-19) but also the common cold (Fehr \& Perlman, 2015; Lim et al., 2016). Thus, coronavirus respiratory syndrome, coronavirus pneumonia, coronavirus flu, or any other variant, is a disease (WHO, 2020c).

Greece was significantly affected by COVID-19. Its appearance in Greece was felt on February 26. These were imported cases of COVID-19 among Greeks who travelled to affected Italy, but also in pilgrims who traveled to Israel and Egypt.

(https://www.civilprotection.gr/el/enimerosi-diapisteymenon-dimosiografon-apo-yfypoyrgo-politikis-prostasias-kaidiaheirisis).

\subsection{The Financial Effects}

The COVID-19 pandemic has caused a huge economic crisis worldwide. The economy of each country affected by the virus has been affected, regardless of the income of each country. Recent data from the UNIDO Industrial Production Index show that low- and middle-income countries have been severely affected by this pandemic (Cantore et al., 2020), as can be seen in Table 1.

Table 1. Average loss in \% in the index of industrial production (IIP) across countries (April 2020)



Source: https://www.unido.org/stories/coronavirus-economic-impact-10-july-2020

According to recent data from the Center for Systems Science and Engineering at Johns Hopkins University, there is a large asymmetry in the number of deaths that occurred by the transmission of this virus per country. Thus, an example is the case of the poorest country in the world, sub-Saharan Africa, where there is no serious influence from the pandemic, compared to the effects that existed in other countries (Cantore et al., 2020), as Figure 1 shows. 


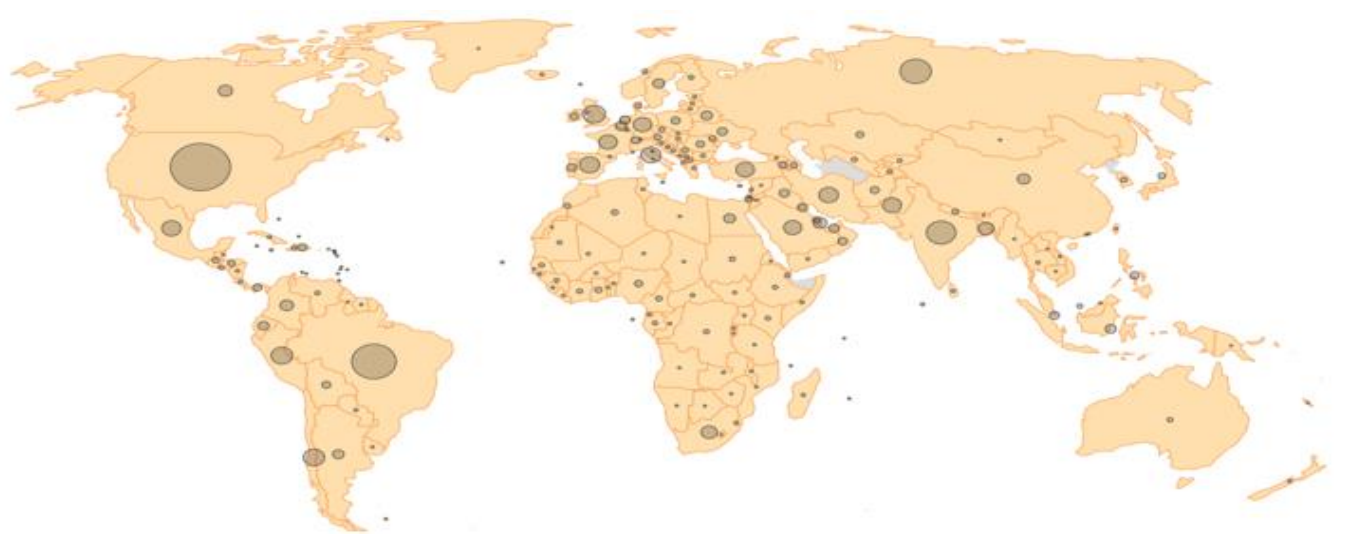

Figure 1. Spread of COVID-19 around the globe

Source:

https://choice.npr.org/index.html?origin=https://www.npr.org/sections/goatsandsoda/2020/03/30/822491838/coronav irus-world-map-tracking-the-spread-of-the-outbreak"?t=1593590785569

According to a study by Noy et al. (2020), the immediate cost of this pandemic seems to be related to the diseases it causes in humans and their mortality. These direct costs, however, are lower compared to the indirect losses incurred. The impact of the pandemic may not be as significant in terms of human mortality, but it is serious financially. Many countries are in recession, and the death toll is not commensurate. Even the few deaths significantly affect businesses in low-income countries due to their poor socioeconomic conditions (vulnerability) and the inability of these countries to respond to economic crises (resilience). In addition, many countries have been indirectly affected by the disruption of the value chain and the decline in international demand for their goods as a result of the global recession.

\subsection{Industrial Production and Exports}

According to the latest statistics obtained from the UNIDO Industrial Production Index (IIP), data from 49 countries showed an economic loss of $87 \%$ of world value-added production. Comparing the data from the IIP for March 2020, when there was a strong and dangerous outbreak of COVID-19, compared to those of December 2019, it appeared that $81 \%$ of countries showed a reduction in industrial production at an average rate of $6 \%$. This comparison also showed that there is a reduction in industrial production by an average of $20 \%$ in $93 \%$ of countries worldwide. Of course, this reduction does not mean that there have been similar effects on human health, as shown in Figure 2 below. In particular, states that had the same rate of COVID-19-infected patients did not have the same level of financial loss, which depends on the containment measures taken and implemented by each state government (Cantore et al., 2020).

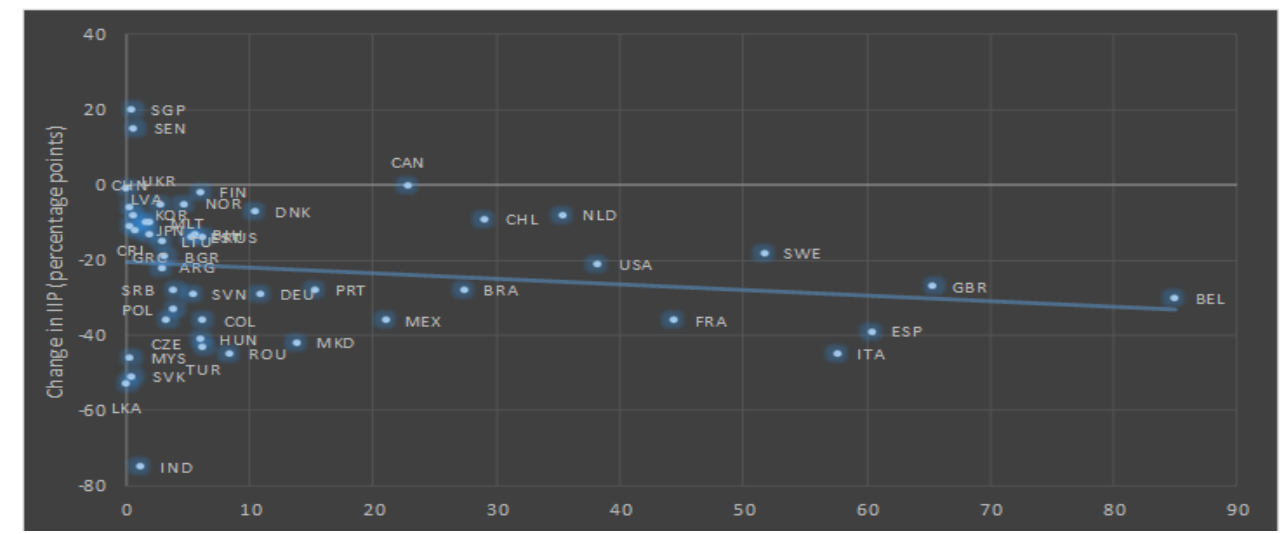

Figure 2. Relationship between decrease in industrial production and COVID-19 (April 2020 vs December 2019)

Source:

https://translate.googleusercontent.com/translate_c?depth=1\&hl=el\&prev=search\&pto=aue\&rurl=translate.google.gr \&sl=en\&sp=nmt4\&u=https://stat.unido.org/COVID-19\&usg=ALkJrhiMefqk2BuZquoF-qKxw6qzb14krg 
The decrease in industrial production showed a heterogeneous distribution in the countries; there were positive prices, but also losses that reached 50\%. According to the India Industrial Production Index, there was a decrease of 65\%. This reveals the drastic reduction in the country's exports due to the pandemic. Countries are generally classified according to the decrease in industrial production, so through this classification, it is possible to compare data by country, with comparative time periods of March 2019 and April 2020. A total of 50\% of the countries in the world suffered from the reduction in their industrial production, which was more than $2 \%$. The average value of the sample regarding the Industrial Production Index is between $20 \%$ to $30 \%$. The majority of countries in the Industrial Production Index worldwide showed a decrease in industrial production of between 10-20\% (Cantore et al., 2020).

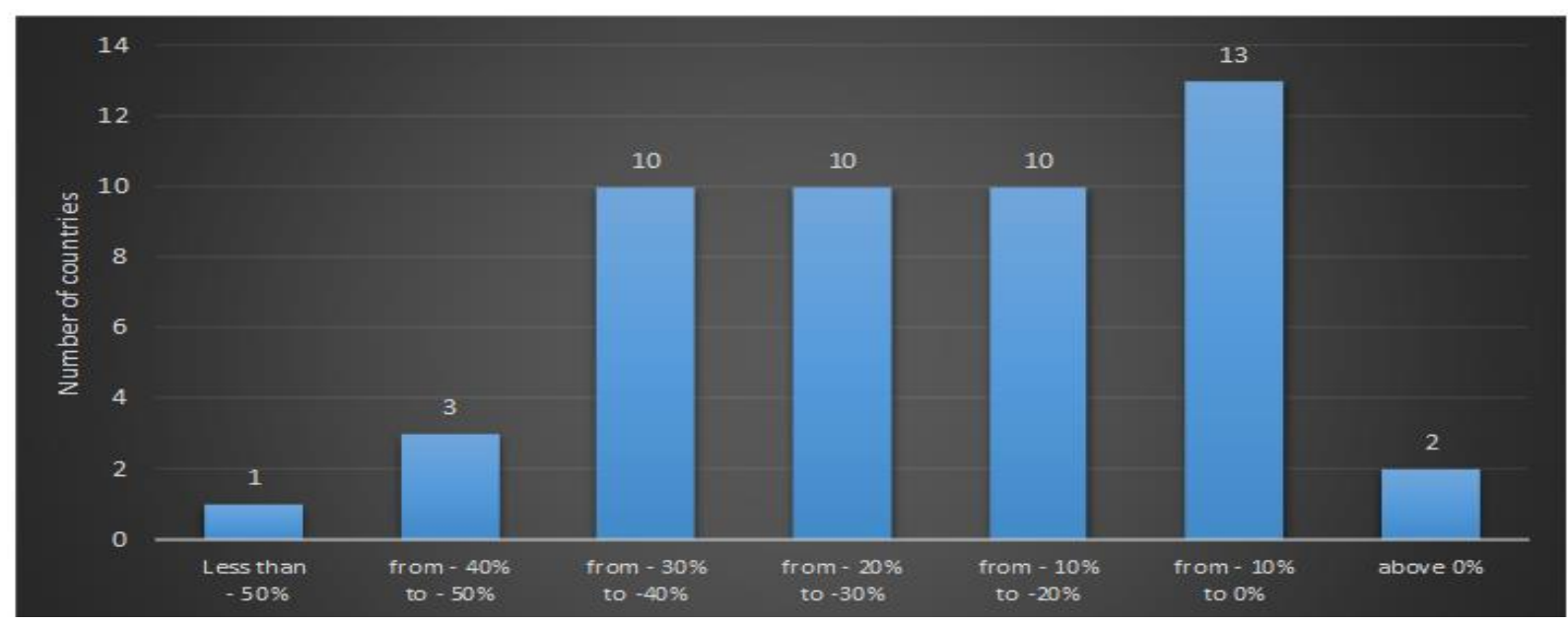

Figure 3. Distribution of decreases in IIP (April 2020 vs December 2019) Across a Sample of 49 Countries Source:

https://translate.googleusercontent.com/translate_c?depth=1\&hl=el\&prev=search\&pto=aue\&rurl=translate.google.gr \&sl=en\&sp=nmt4\&u=https://stat.unido.org/COVID-19\&usg=ALkJrhiMefqk2BuZquoF-qKxw6qzb14krg

Generally, during the month of April 2020 (i.e., during the COVID-19 pandemic), there was a deterioration in industrial production compared to industrial production during non-pandemic measurements (i.e., March 2019). The decrease in industrial production continued to exist in $90 \%$ of the countries in the world, with an average fall in industrial production of $15 \%$ each month. The monthly decline was more pronounced in India, where it reached 55\%, in Northern Macedonia, with a decrease of 35\%, in Malaysia, with a decrease of 34\%, in Turkey, with a decrease of $33 \%$ and in Slovenia, where the reduction reached 32\%. On the other hand, industrial production increased in some countries, such as Senegal, with an increase of 9\%, Canada, with an increase of 7\%, and Singapore, with an increase of $4 \%$ (Cantore et al., 2020).

There was a decisive impact on the manufacturing industries due to the economic crisis as a result of the outbreak of the COVID-19 pandemic, as shown by comparative data between March 2019 and April 2020. Countries experienced a global decline in manufacturing of 55\% in the pharmaceutical industry and up to $94 \%$ in the automotive industry. The pharmaceutical industry was one of the exceptions, as some pharmaceutical companies were hit harder than others. Some pharma companies fared better than others. On the other hand, every automotive industry has suffered a huge financial blow. The negative trend of the economic crisis continued after April for every industry in the world, with the pharmaceutical industry being less economically affected compared to other sectors of world industrial production (Cantore et al., 2020), as Figure 4 shows. 




Figure 4. Share of countries (\%) registering a decrease in industrial production over the period March - April 2020 in different industries

Source:

https://translate.googleusercontent.com/translate_c?depth=1\&hl=el\&prev=search\&pto=aue\&rurl=translate.google.gr $\& s l=e n \& s p=n m t 4 \& u=h t t p s: / / s t a t . u n i d o . o r g / C O V I D-19 \& u s g=A L k J r h i M e f q k 2 B u Z q u o F-q K x w 6 q z b 14 k r g$

\subsection{Trade Losses Due to the Pandemic}

From the studies that were conducted on commercial trends, for March and April of 2020, results showed it does not deviate much from the trend that existed in the industrial production as well. In all, 43 of the 46 countries surveyed worldwide showed a reduced level of their commercial goods. The largest decrease in trade was observed in South Africa, India, Mexico, France, and Italy. China recovered quickly, while Israel, China, and Chile increased their trade during the pandemic. The 10 countries that showed the largest decrease in trade quantitatively are countries that are distinguished for their higher incomes. Therefore the pandemic had a negative impact on the industry and trade of developed and developing countries (Cantore et al., 2020), as shown in Figure 5.

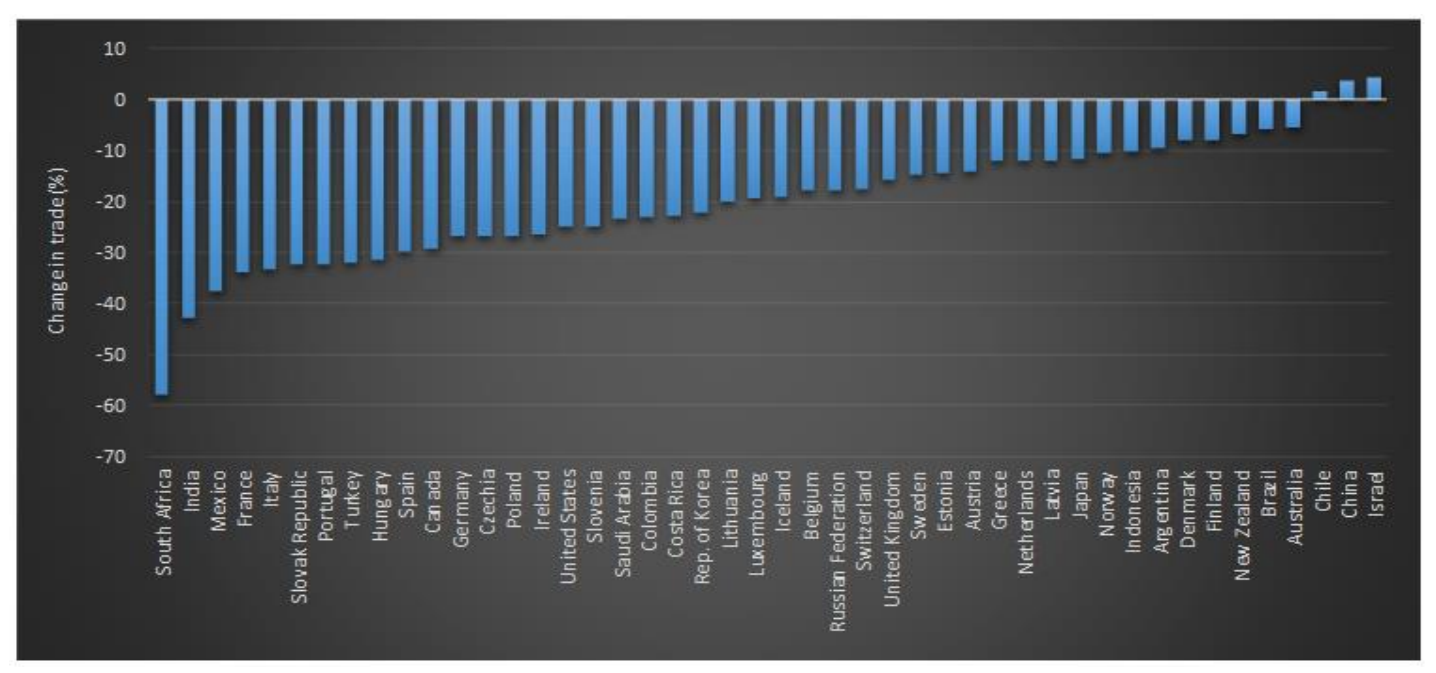

Figure 5. Change of trade in goods in \% by country for the period March - April 2020Source:

https://translate.googleusercontent.com/translate_c?depth=1\&hl=el\&prev=search\&pto=aue\&rurl=translate.google.gr $\& s \mathrm{l}=\mathrm{en} \& \mathrm{sp}=\mathrm{nmt} 4 \& \mathrm{u}=\mathrm{https} / / / \mathrm{stats}$. oecd.org/Index.aspx\%3FDataSetCode\%3DMEI_TRD\&usg=ALkJrhiuX8yTryxsZ CM-v7VYQ2a74CfdJg

COVID-19, therefore, affected most countries around the world. Based on primary research data gathered from the 
UNIDO survey, for many Asian countries, there is preliminary evidence of the effects on their businesses (Cantore et al., 2020), as shown below.

\subsection{The Effects of COVID-19 on Business}

The pandemic has affected all industries, and how much it has affected them depends on the restrictive measures taken by each country. Of course, these restrictive measures affected the processing companies. Key determinants for economic growth in companies are the extent of firms' productive capacities, their degree of integration in domestic and global production networks, and the type of market they serve. Thus, in some countries, companies were able to respond quickly to the demands of the "new age" of the pandemic and adjust their activities accordingly, limiting the overall impact of COVID-19 on their profits, cash flow, and staff (Cantore et al., 2020).

After COVID-19 was declared a pandemic period by the World Health Organization, for more than 3 months, the industrial data from businesses were limited, despite three corporate surveys conducted by national and international organizations worldwide. Each country has made an effort to analyze the impact of this crisis on business, such as ESIEC at Peking University. However, it was difficult to locate business data and thus compare the impact on companies from the pandemic for each country worldwide (Cantore et al., 2020).

This is a serious research gap. However, to fill this research gap, UNIDO conducted pilot surveys for companies, specifically for manufacturing companies in Asian countries. From the first pilot survey, 1,400 valid responses were collected from seven countries. This electronic survey was conducted from mid-April 2020 until early June 2020 , with the cooperation of governments, chambers of commerce, and other organizations operating in these seven countries. Through the research results, information was gathered on the various effects that the pandemic had on each country's industry and businesses, while data were also collected on the reactions of each government and companies in each country (Cantore et al., 2020). The results are shown in Figure 6.

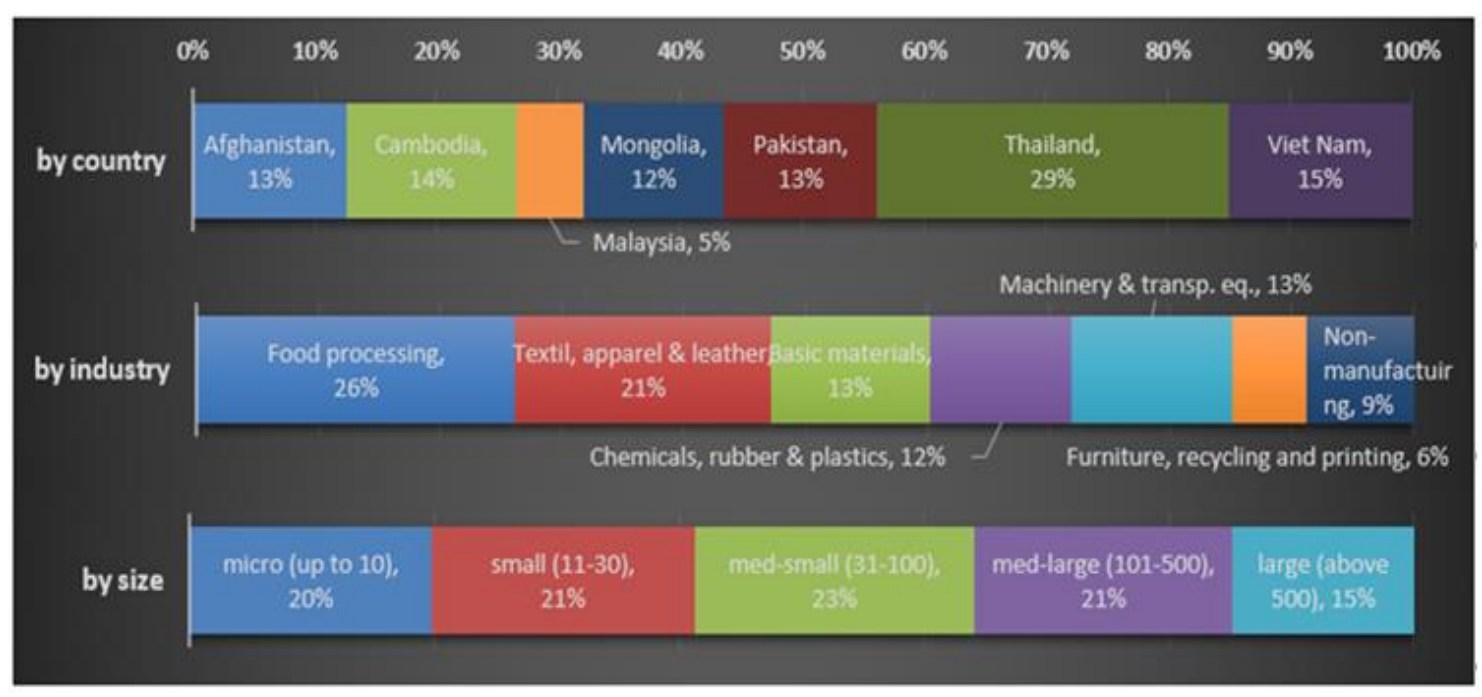

Figure 6. Distribution of sample by country, industry and firm size

Source: https://www.unido.org/stories/coronavirus-economic-impact-10-july-2020

\subsection{The Short-Term Effects of the Pandemic}

The effects of the pandemic in the Asian countries mentioned above per 100,000 inhabitants vary between countries, as shown in the following table. Thus, more than 80 cases per 100,000 inhabitants were reported from Pakistan and Afghanistan and less than five cases per 100,000 inhabitants were reported from Thailand, Cambodia, and Vietnam. The difference between the countries is also seen in the companies that reported that more than half of their employees were unemployed because they could not work during the pandemic. Thus, there was a greater negative impact on the operations in Afghanistan and Pakistan than on the operations in Thailand and Vietnam. More than half of employees in Malaysia and Mongolia reported they were unemployed at the time of the pandemic. In fact, the actual number of people infected by COVID-19 was not the only factor that pushed the unemployment in companies and enterprises. More than one-third of companies stated that at least half of their employees did not work during the pandemic 
(Cantore et al., 2020).

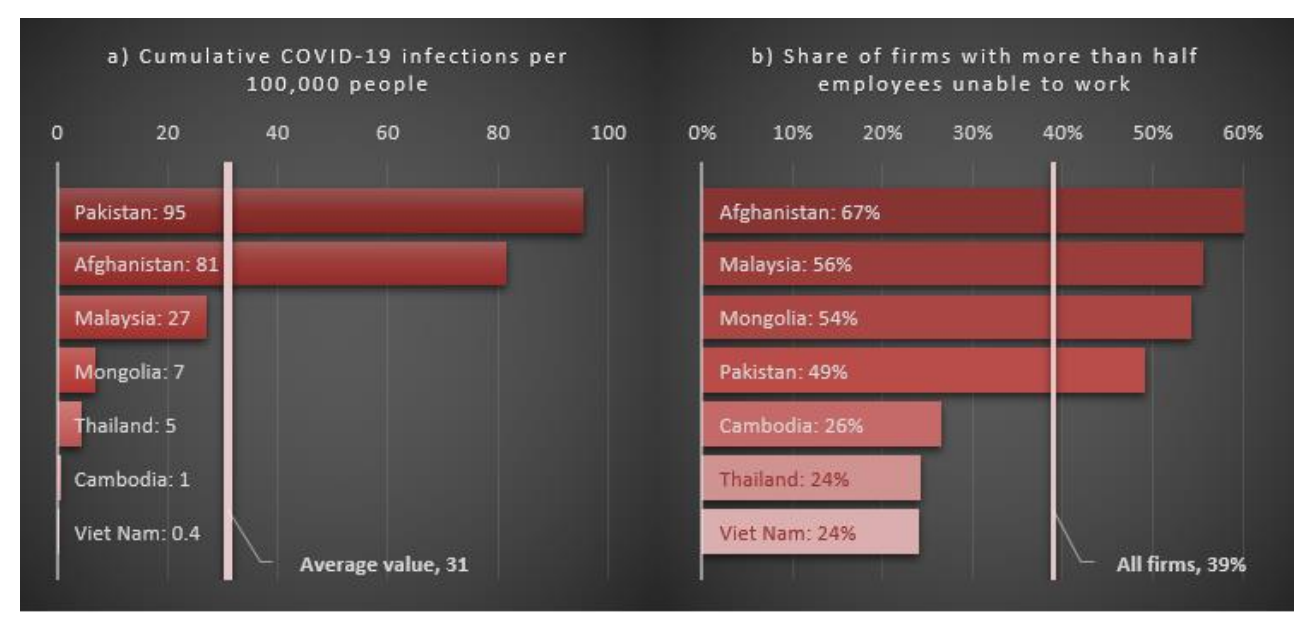

Figure 7. The current impact of COVID-19 in selected Asian countries

Source: https://www.unido.org/stories/coronavirus-economic-impact-10-july-2020

\subsection{Job Prospects in a Pandemic}

There are different figures regarding companies' expectations for their future business profits and for the increase in employment $-50 \%$ of companies in the countries surveyed answered that they expect an active reduction in their company's profits for 2020, as shown in Figure 8. Also, 20\% of companies stated that they had already laid off employees . The majority of companies, in fact, expect cuts in their profits and employment, as demonstrated by companies in Mongolia and Afghanistan (Cantore et al., 2020).



Figure 8. The expected impact of COVID-19 on firms' profits and employment, by countrySource: https://www.unido.org/stories/coronavirus-economic-impact-10-july-2020

The majority of workers lost their jobs or saw a reduction in income due to the crisis caused by the pandemic. Thus, unemployment increased dramatically in large economies (Jones et al., 2020), as shown in Figure 9. 


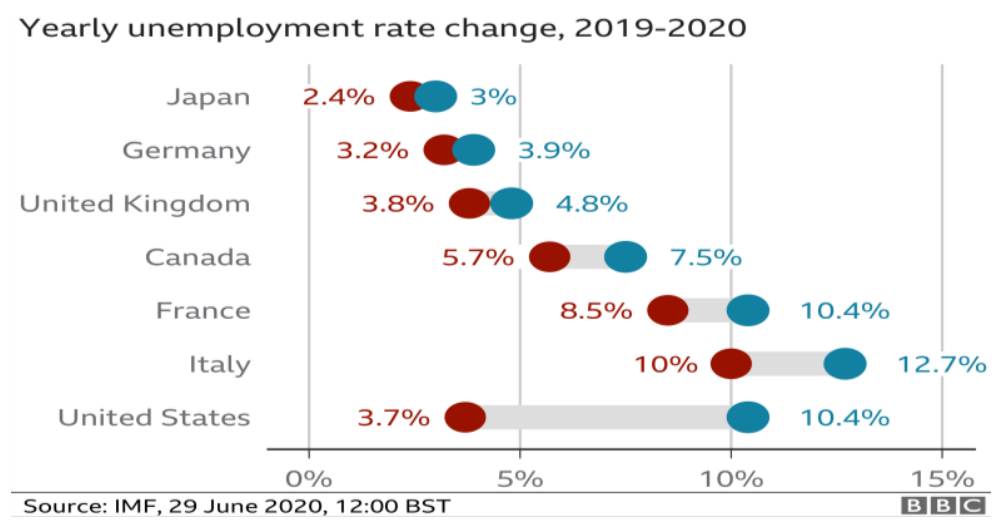

Figure 9. World economies struggling with rising unemployment

In the United States, $10.4 \%$ of the population is not working, according to the International Monetary Fund, which means that the decade of expansion in one of the largest economies in the world is over. Millions of workers have maintained their jobs through the support they received from the government, while tourism and hospitality are at a stand-still. Of course, each country is experiencing different conditions. (Jones et al., 2020; OECD, 2020), as shown in Figure 10.



Figure 10. Millions of workers furloughed

There have been signs that the economy is recovering in the global labor market. Examples are China and France, where recruitment rates have increased and downtime has declined, according to LinkedIn Corporation (2020).



Figure 11. Linkedln hiring rate by country

Some experts have reported that employment data are only available from before the pandemic, so they are unsure 
about the cause of the pandemic in the employment situation (Jones et al., 2020). According to the International Monetary Fund (2020), if the economy grows, wealth will increase, and jobs will increase and multiply. It is the count according to a percentage change of the gross domestic product or the value of the goods and services produced in a period of 3 months or in a year. According to the International Monetary Fund, the world economy will shrink by 3\% for 2020. In fact, the decline in the global economy is described as the biggest recession since 1930.



Figure 12

\subsection{The Travel Industry}

The travel industry has been hit hard. Airlines have suspended flights, and many of their potential customers are canceling their business trips and vacations. In many countries, travel restrictions have been introduced in an effort to curb the virus. Thus, according to data provided by Flight Radar flight monitoring service 24/7 (Petchenik, 2020), flights worldwide were a huge success for the year 2020, as shown in Figure 13.



Figure 13. Flights picking up again (Number of total daily flights)

As the pandemic spread, there were reductions in certain areas, and industry began to open up. An example is Spain, which has reopened its entry gates to tourists from all over Europe, without quarantining them. For months, Spain was under quarantine and blocked entrance to visitors from any country. Private companies also reported that there has been a huge volume of seat bookings from the UK as the country's restrictions have been lifted (Jones et al., 2020). Until the current pandemic, which reduced and zeroed in many cases the use and value of products, services (private and public), and resources included in tourism, there was the impression that it was mainly the environmental and the economic trends representing the most influential and diversifying activity Chatzitheodoridis et al., 2020).

\subsection{Product Oil Prices}

The demand for oil was affected by the global quarantine lock down situation. The price of crude oil was affected by competition between OPEC, the oil producer group, and Russia. During the pandemic, the price of oil fell significantly (Jones et al., 2020). 




Figure 14. Oil price in 2020 (Brent crude, US dollars per barrel)

Brent crude oil is an example of a product used by Europe and the rest of the world. Its price fell to $\$ 20$, an unprecedented phenomenon over the past 18 years. Oil prices certainly returned, as the restriction on drivers no longer existed, so the demand for fuel grew (Jones et al., 2020).

\subsection{Consumer Confidence}

Retail trade also fell sharply, unprecedented for years. Buyers/consumers were locked in their homes due to quarantine, trying to stop the spread of COVID-19. Thus, they did not go to the market in order to shop. Of course, pedestrians in the market have since increased, as quarantine and home restraint measures have eased, according to Shopper Trak (Jones et al., 2020).

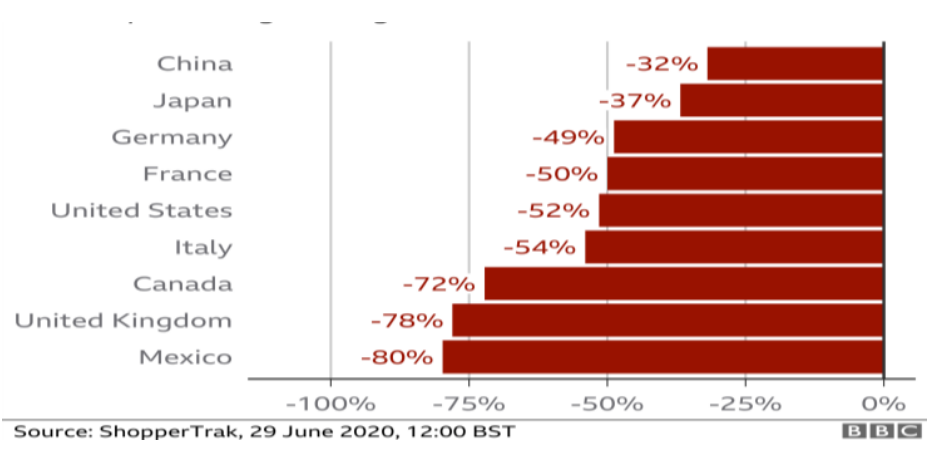

Figure 15. Huge drop in shoppers (Annual percentage change of footfall in 14-20 June)

Source: https://www.bbc.com/news/business-51706225

\subsection{The Vaccine Issue}

Globally, governments have spent billions of dollars to find an effective vaccine to treat patients with COVID-19. Some pharmaceutical companies are struggling to develop and test a variety of drugs to help countries return to normal health and normal living conditions, namely prior to COVID-19 (Jones et al., 2020).

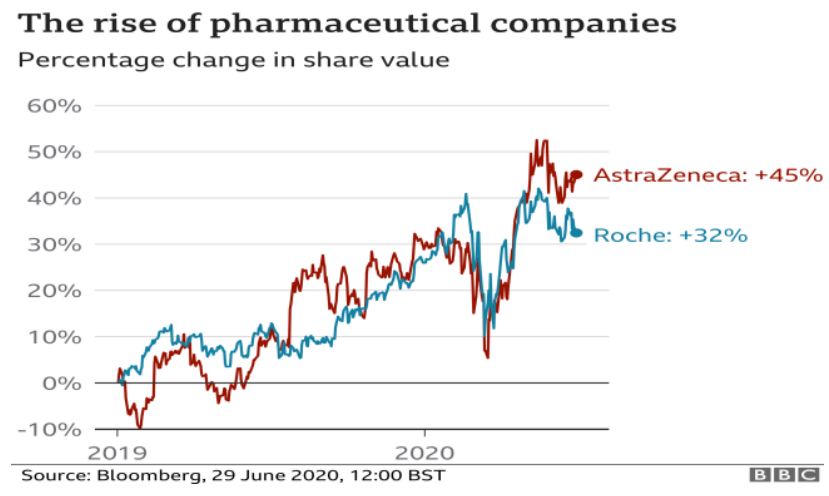

Figure 16 
Thus, the shares in some pharmaceutical companies have increased, raising the hopes that an effective vaccine will be approved and distributed safely. In particular, the share price of the pharmaceutical company AstraZeneca reached record prices. The pharmaceutical company states that it can produce 2 billion doses of the vaccine (https://www.bbc.co.uk/news/business-52917118). On the other hand, according to official statements from the International Monetary Fund (Jones et al., 2020), no country is safe until the appropriate COVID-19 vaccine is released.

\subsection{The Impact of the Pandemic on Individual Industries}

Not all industries have been affected in the same way and to the same extent. Companies related to the textile, clothing, and leather industries are expected to be hit severely in terms of profits and jobs. Businesses associated with the chemical and plastics and rubber industries, on the other hand, expected their profits to be cut by less than half, as shown in Figure 17 below. The raw material industries will be hit even harder in terms of profits and employment. Furniture, recycling, and printing industries expect a significant reduction in their profits is expected, as answered by $54 \%$ of the companies that participated in the survey, while $16 \%$ of the companies in these sectors will be forced to announce drastic job cuts. This is the average answer of those who responded in the survey. Similar trends seem to exist for the machinery and transport equipment industries (Cantore et al., 2020).

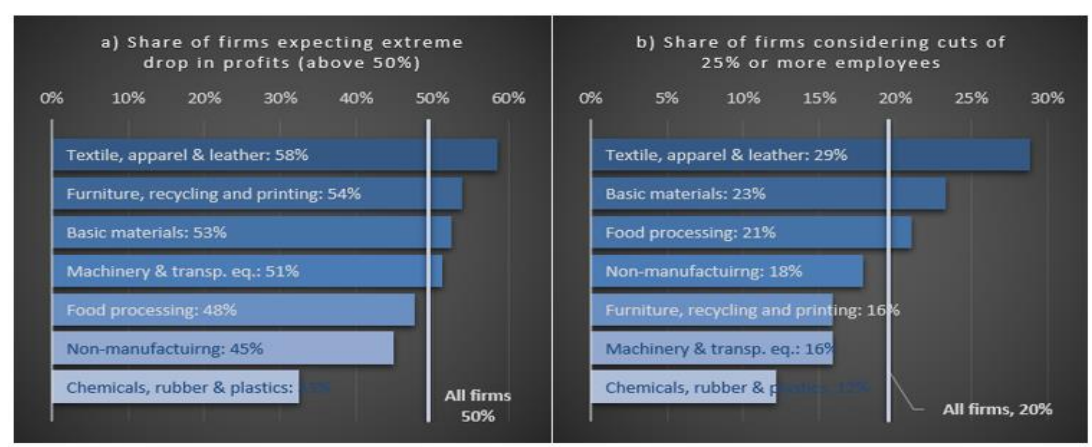

Figure 17. Expected impact of COVID-19 on firms' profits and employment, by industry

Source: https://www.unido.org/stories/coronavirus-economic-impact-10-july-2020

\subsection{The Problems of Industries}

Businesses state different expectations from the pandemic challenges they face, as shown in Figure 18. The two main challenges that industries state they face are that market demand has declined as well as difficulties in paying their employees. The biggest problem for the textile and clothing industries is the payment of their employees' salaries. Many industries also seem to be facing the problem of the reduction of the demand for their products. Also, textile and clothing companies and their affiliates are concerned about their supply. Finally, there is great concern for the chemical, rubber, and plastics industries about impacts in their supply chains, which will be accompanied by a chain reaction for their partner companies or enterprises (Cantore et al., 2020).

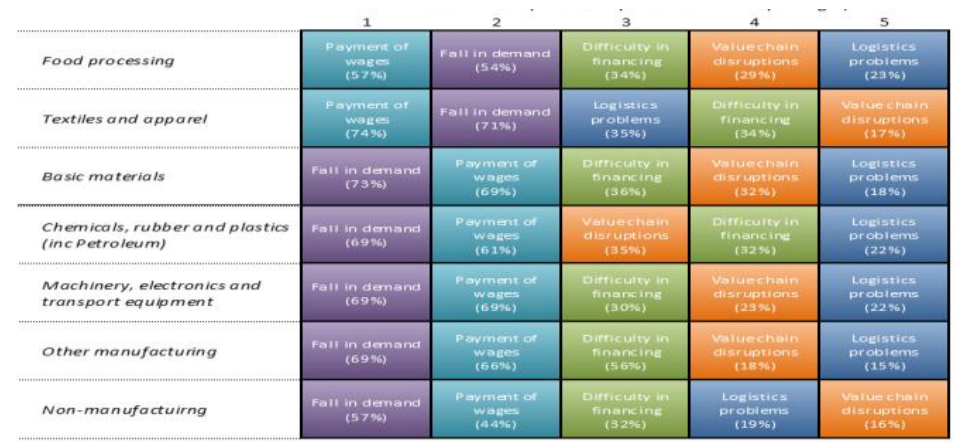

Figure 18. Top 5 problems reported by firms, across industries

Source: https://www.unido.org/stories/coronavirus-economic-impact-10-july-2020 


\subsection{The Size of the Company in Relation to the Effects of the Pandemic on Profits and Employment}

It seems that the size of the company plays an important role in the impact of the pandemic on its profits and the issue of employment of its employees. Specifically, as Figure 19 shows, the smaller companies that are expanding predict a greater reduction in their profits compared to the statements made by the larger companies. A similar phenomenon exists in the issue of employment: smaller companies acknowledge they will cut staff, while larger companies state that their staff cuts will be limited (Cantore et al., 2020).

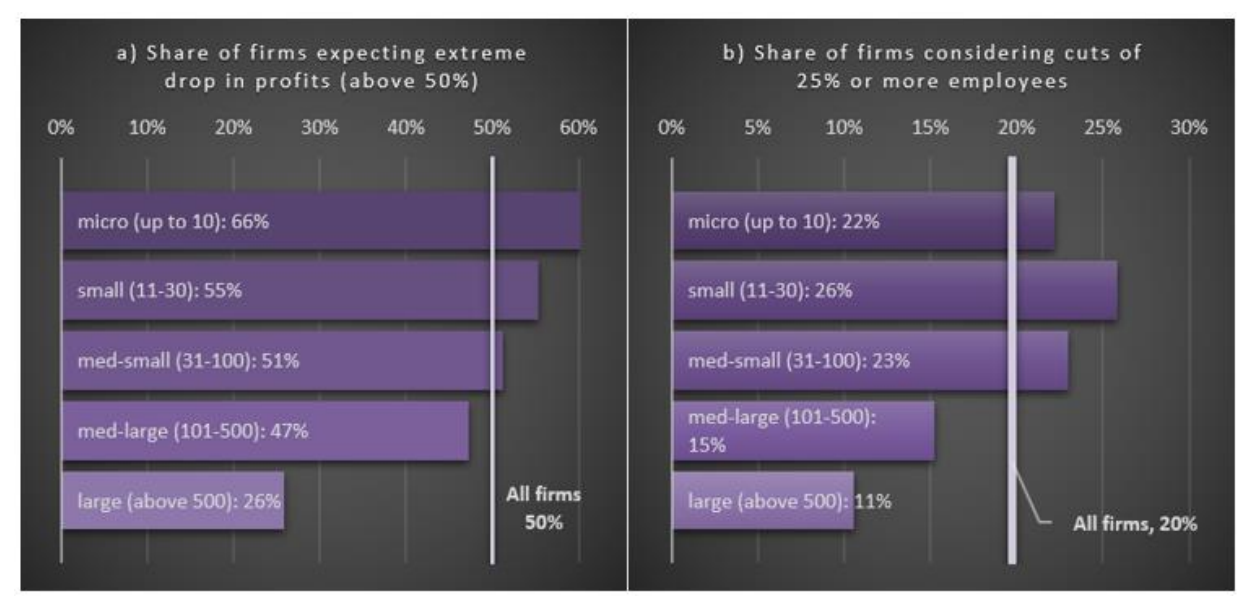

Figure 19. Expected impact of COVID-19 on firms' profits and employment, by firm size

Source: https://www.unido.org/stories/coronavirus-economic-impact-10-july-2020

\subsection{Comparison of Problems Faced by Companies and Firms}

Small and medium-sized enterprises face the biggest problems regarding the payment of salaries to their employees. Medium and large companies also have difficulty in paying salaries to employees, but to a lesser extent. The main problem medium and large enterprises face is the disruption of the value chain due to the pandemic (Cantore et al., 2020).

\begin{tabular}{|c|c|c|c|c|c|}
\hline & 1 & 2 & 3 & 4 & 5 \\
\hline Food processing & $\begin{array}{l}\text { Payment of } \\
\text { wages } \\
\text { (57\%) }\end{array}$ & $\begin{array}{l}\text { Fall in demand } \\
(5496)\end{array}$ & $\begin{array}{l}\text { Difficulty in } \\
\text { financing } \\
\text { (34\%) }\end{array}$ & $\begin{array}{l}\text { Valuechain } \\
\text { disruptions } \\
(29 \%)\end{array}$ & $\begin{array}{l}\text { Logistics } \\
\text { problems } \\
(23 \%)\end{array}$ \\
\hline Textiles and apparel & $\begin{array}{l}\text { Payment of } \\
\text { wage } \\
(74 \%)\end{array}$ & $\begin{array}{c}\text { Fall in demand } \\
(71 \%)\end{array}$ & $\begin{array}{l}\text { Logistics } \\
\text { problems } \\
\text { (35\%) }\end{array}$ & $\begin{array}{l}\text { Difficuity in } \\
\text { financing } \\
(34 \%)\end{array}$ & $\begin{array}{l}\text { Value chain } \\
\text { disruptions } \\
\text { (17\%6) }\end{array}$ \\
\hline Basic materials & $\begin{array}{l}\text { Fall in demand } \\
(739 \%)\end{array}$ & $\begin{array}{l}\text { Payment of } \\
\text { wages } \\
\text { (69\%) }\end{array}$ & $\begin{array}{c}\text { Difficuity in } \\
\text { financing } \\
(36 \%)\end{array}$ & $\begin{array}{l}\text { Valuechain } \\
\text { disruptions } \\
(32 \%)\end{array}$ & $\begin{array}{l}\text { Logistics } \\
\text { problems } \\
(18 \%)\end{array}$ \\
\hline $\begin{array}{l}\text { Chemicals, rubber and plastics } \\
\text { (inc Petroleum) }\end{array}$ & $\begin{array}{l}\text { Fall in demand } \\
(69 \%)\end{array}$ & $\begin{array}{l}\text { Payment of } \\
\text { wages } \\
\text { (61\%) }\end{array}$ & $\begin{array}{l}\text { Valuechain } \\
\text { disruptions } \\
\text { (35\%) }\end{array}$ & $\begin{array}{l}\text { Difficulty in } \\
\text { financing } \\
(32 \%)\end{array}$ & $\begin{array}{l}\text { Logistics } \\
\text { problems } \\
(22 \%)\end{array}$ \\
\hline $\begin{array}{l}\text { Machinery, electronics and } \\
\text { transport equipment }\end{array}$ & $\begin{array}{l}\text { Fall in demand } \\
(69 \%)\end{array}$ & $\begin{array}{l}\text { Payment of } \\
\text { wages } \\
\text { (69\%) }\end{array}$ & $\begin{array}{l}\text { Difficulty in } \\
\text { financing } \\
\text { (30\%) }\end{array}$ & $\begin{array}{l}\text { Valuechain } \\
\text { disruptions } \\
\text { (23\%) }\end{array}$ & $\begin{array}{l}\text { Logistics } \\
\text { problems } \\
(22 \%)\end{array}$ \\
\hline other manufacturing & $\begin{array}{l}\text { Fall in demand } \\
(69 \%)\end{array}$ & $\begin{array}{l}\text { Payment of } \\
\text { wages } \\
\text { (66\%) }\end{array}$ & $\begin{array}{l}\text { Difficulty in } \\
\text { financing } \\
(56 \%)\end{array}$ & $\begin{array}{l}\text { Valuechain } \\
\text { disruptions } \\
\text { (18\%) }\end{array}$ & $\begin{array}{c}\text { Logistics } \\
\text { problems } \\
(15 \%)\end{array}$ \\
\hline Non-manufactuirng & $\begin{array}{l}\text { Fall in demand } \\
(57 \%)\end{array}$ & $\begin{array}{l}\text { Payment of } \\
\text { wages } \\
\text { (44\%) }\end{array}$ & $\begin{array}{l}\text { Difficulty in } \\
\text { financing } \\
(32 \%)\end{array}$ & $\begin{array}{l}\text { Logistics } \\
\text { problems } \\
(19 \%)\end{array}$ & $\begin{array}{c}\text { Value chain } \\
\text { disruptions } \\
\text { (16\%) }\end{array}$ \\
\hline
\end{tabular}

Figure 20. Top 5 problems reported by firms, across size

Source: https://www.unido.org/stories/coronavirus-economic-impact-10-july-2020

\section{Stock Market Flows}

Changes that may occur in the stock markets in which companies' shares are bought and sold have a significant effect on the value of pensions and individual savings accounts. During the pandemic, therefore, there were serious falls in 
the shares of the companies FTSE, Dow Jones Industrial Average, and Nikkei. In particular, the two aforementioned companies saw significant stock market declines (Jones et al., 2020), as shown schematically below in Figure 21.

\section{The impact of coronavirus on stock markets since the start of the outbreak}

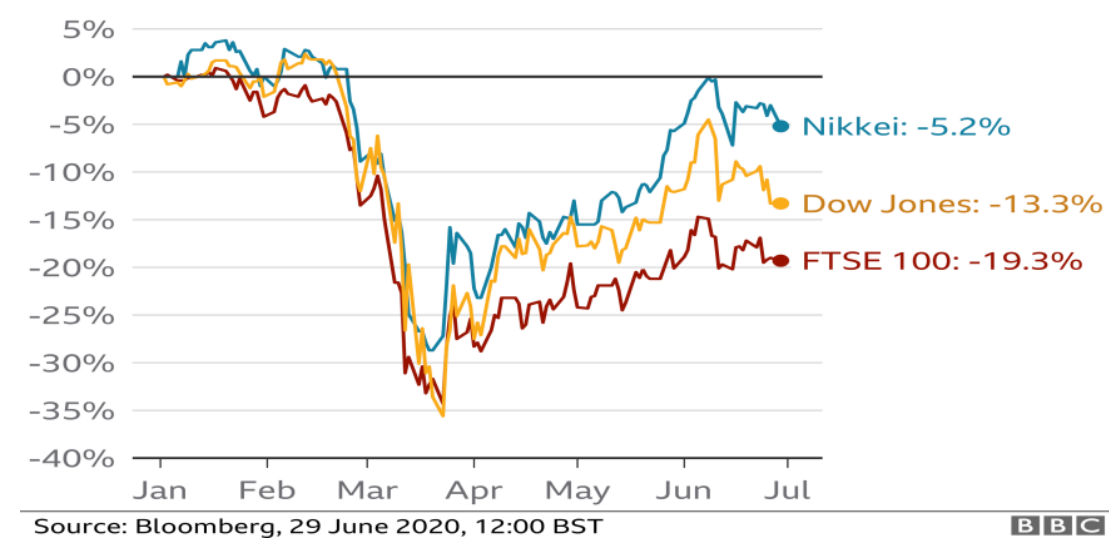

Figure 21

Because of the serious impact of the pandemic, the central banks of many countries, such as the United Kingdom, have cut interest rates. In particular, they have made lending cheaper and encouraged spending to boost the economy. After that, the world market recovered with the intervention of governments. Of course, according to some analysts, this recovery is currently unstable because there is a strong fear of a second wave of the pandemic (Jones et al., 2020).

\subsection{Policies to Deal With the Economic Crisis Due to the Pandemic}

Generally, examining the implemented policies adopted by countries and their governments reveals how effective these policies have been. In general, it also seems that the trend has changed from supporting the cash flows of companies and households to measures to help industries and businesses become more productive (Cantore et al., 2020).

According to companies, the most common form of government policy support is tax deferrals or tax cuts, utility cost cuts, loan deferrals, and favorable business financing as well as bans on layoffs of staff and financial support in general. Postponement of tax liabilities, in fact, seems to be a global policy (Cantore et al., 2020).

Regarding the way the OECD and G20 countries deal with the pandemic, Bulman and Koirala (2020) found that postponement of taxes and social security payments is the most common tax instrument applied worldwide. Thus, as of May 13, 2020, out of a total of more than 90 countries worldwide affected by the pandemic, $96 \%$ covered by the COVID-19 Policy Tracker of OECD are implementing these measures. Globally, it appears that $93 \%$ of countries have implemented corporate subsidy policies, $91 \%$ have enacted household income support policies, $89 \%$ have applied wage subsidy policies, and $80 \%$ have implemented tax cuts/social security and transfer of cash/grants to state enterprises.

The majority of companies participating in the UNIDO survey said that reductions in taxes and rents and reductions in utility costs are the key measures taken by their country. Specifically, 39\% of Mongolian businesses and 79\% of Afghan businesses cited tax cuts as their main national measure against the crisis caused by the pandemic. Further, $32 \%$ of Mongolian businesses and 63\% of Afghan businesses, as shown in figure 2, have called for a reduction in ren and utility costs (Cantore et al., 2020). This finding is consistent with research conducted by the World Bank in the context of monitoring the impact of COVID-19 on Ethiopian companies (Abebe et al., 2020). Simply put, in this survey, the majority of companies believe that tax exemption is preferable to meet the challenges of the pandemic. 


\begin{tabular}{|c|c|c|c|c|c|}
\hline & 1 & 2 & 3 & 4 & 5 \\
\hline Afghanistan & $\begin{array}{c}\text { Reduce tax rates or } \\
\text { defer tax } \\
(76 \%)\end{array}$ & $\begin{array}{l}\text { Reduce rent and lower } \\
\text { utilities costs } \\
\qquad(63 \%)\end{array}$ & \begin{tabular}{|c|} 
Reducefinancing \\
costs or improve loan \\
terms \\
$(20 \%)$
\end{tabular} & $\begin{array}{l}\text { Optimize exporting rax } \\
\text { rebateservices } \\
\text { (10\%) }\end{array}$ & $\begin{array}{c}\text { Temporary reduction } \\
\text { of social benefits } \\
\text { (7\%) }\end{array}$ \\
\hline Malaysia & $\begin{array}{c}\text { Reduce tax rates or } \\
\text { defe tax } \\
(55 \%)\end{array}$ & $\begin{array}{l}\text { Reduce rent and lowe } \\
\text { utilities costs } \\
\qquad(32 \%)\end{array}$ & \begin{tabular}{|c|} 
Reducefinancing \\
costs or improveloan \\
terms \\
$(20 \%)$ \\
\end{tabular} & $\begin{array}{c}\text { Optimize exporting tax } \\
\text { rebateservices } \\
\text { (13\%) }\end{array}$ & $\begin{array}{c}\text { Temporary reduction } \\
\text { of social benefits } \\
(9 \%)\end{array}$ \\
\hline Mongolia & $\begin{array}{l}\text { Temporary reduction } \\
\text { of social benefits } \\
\text { (41\%) }\end{array}$ & $\begin{array}{l}\text { Reducetax rates or } \\
\text { defer tax } \\
(39 \%)\end{array}$ & \begin{tabular}{|c|} 
Reducefinancing \\
costs or improve loan \\
terms \\
$(38 \%)$ \\
\end{tabular} & $\begin{array}{c}\text { Reducerent and lower } \\
\text { utilities costs } \\
(32 \%)\end{array}$ & $\begin{array}{l}\text { Optimizeexporting tax } \\
\text { rebate services } \\
\text { (7\%) }\end{array}$ \\
\hline Pakistan & $\begin{array}{c}\text { Reduce tax rates or } \\
\text { defe tax } \\
(58 \%)\end{array}$ & $\begin{array}{l}\text { Reduce rent and lowe } \\
\text { utilities costs } \\
\qquad(45 \%)\end{array}$ & \begin{tabular}{|c|} 
Reducefinanting \\
costs or improve loan \\
terms \\
$(299)$ \\
\end{tabular} & $\begin{array}{l}\text { Optimize exporting rax } \\
\text { rebateservices } \\
\text { (24\%) }\end{array}$ & $\begin{array}{c}\text { Temporary reduction } \\
\text { of social benefits } \\
\text { (5\%) }\end{array}$ \\
\hline Thailand & $\begin{array}{c}\text { Reduce tax rates or } \\
\text { defer tax } \\
(52 \%)\end{array}$ & $\begin{array}{c}\text { Temporary reduction } \\
\text { of social benefits } \\
(37 \%)\end{array}$ & $\begin{array}{l}\text { Reduce rent and lower } \\
\text { utilities costs } \\
(33 \%)\end{array}$ & \begin{tabular}{|c|} 
Reduce financing \\
costs or improve loan \\
terms \\
$(28 \%)$ \\
\end{tabular} & $\begin{array}{l}\text { Optimizeexporting tax } \\
\text { rebateservices } \\
\text { (7\%) }\end{array}$ \\
\hline Viet $\mathrm{Nam}$ & $\begin{array}{c}\text { Reduce tax rates or } \\
\text { defer tax } \\
(54 \%)\end{array}$ & $\begin{array}{l}\text { Reduce rent and lowe } \\
\text { utilities costs } \\
\qquad(41 \%)\end{array}$ & $\begin{array}{c}\text { Temporary reduction } \\
\text { of social benefits } \\
(39 \%)\end{array}$ & $\begin{array}{c}\text { Resuce financing } \\
\text { costs or improve loan } \\
\text { terms } \\
\text { (30\%) }\end{array}$ & $\begin{array}{c}\text { Optimizeexporting tax } \\
\text { rebate services } \\
\text { (1096) }\end{array}$ \\
\hline
\end{tabular}

Figure 22. Policies governments should implement, as indicated by firms (\%)

Source: https://www.unido.org/stories/coronavirus-economic-impact-10-july-2020

In a UNIDO survey conducted in Mongolia, Pakistan, and Thailand, companies in those countries answered how useful they found the measures taken by their governments; $72 \%$ of Mongolian companies, $77 \%$ of Pakistani companies, and $73 \%$ of Thai companies said that direct financial support from the government was very beneficial for the crisis (Cantore et al., 2020).

The OECD (2020) analyzed the impact of the three key government measures aimed at strengthening and supporting companies financially affected by COVID-19: tax deferrals, debt relief, and temporary support for wage payments. From this analysis, the scenarios concerning the financial data of companies from the Orbis data were investigated by OECD. The first scenario concerns business support, which is abundant. The second scenario concerns financial support. Support for wage payments is an effective measure, while the measure of tax deferrals seemed to have less impact on corporate cash flows. According to the same OECD study, if all three measures were combined, as mentioned above, within 2 months the number of companies affected would be reduced by $20 \%$ (OECD, 2020).

UNIDO research shows that government efficiency is paramount to the speed and effectiveness of pandemic crisis response measures. Based on some elements of business support, contrary to the expectations of companies from government measures, questions are raised concerning government choices that could adapt industrial policy measures and packages (Cantore et al., 2020).

The UNIDO shows that $10 \%$ of businesses in Afghanistan and Vietnam and 50\% of businesses in Malaysia and Mongolia have benefited and been stimulated by government measures. As Figure 23 shows, larger companies are more likely to receive government support than small businesses, which are more vulnerable and have more difficulty accessing finance. In Malaysia alone, this is not the case with business size, as $70 \%$ of small businesses have received government support (Cantore et al., 2020). 


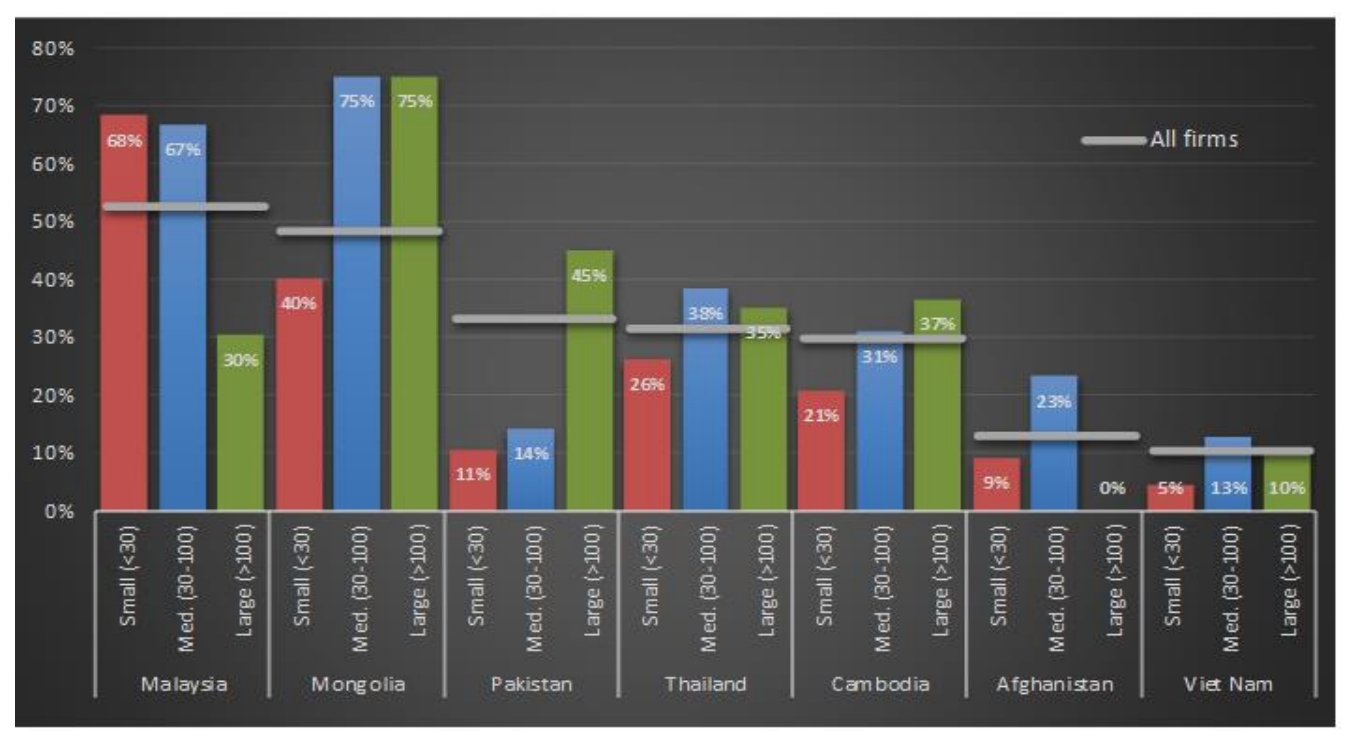

Figure 23. Share of firms benefitting from government support by firm size (\%)

Source: https://www.unido.org/stories/coronavirus-economic-impact-10-july-2020

The effects of the pandemic on businesses and the economic downturn that followed the outbreak of COVID-19 have forced many governments to start investigating whether it favors the country's businesses so that they can grow inclusively. An example is the European Union recovery plan, which implemented a recovery and resilience mechanism in European countries, in the context of Europe's green and digital transitions. The International Monetary Fund has proposed green recovery plans as they work on structural reforms for macroeconomic growth. Few countries have followed this plan, such as the Republic of Korea, Germany and the United States, which have promoted greenery in the construction sector (IISD, 2020).

Other countries have used government funds to create more resilient health care systems (WHO, 2020a). Also, the use of state funds that were implemented aimed at reducing their dependence on the import of basic goods. The funds that governments have, therefore, mitigated the effects of the conditional pandemic and led to the healthier, more resilient and productive economy of the country (Mazzucato \& Andreoni, 2020). To make this possible, of course, each country had to be able to design, implement and enforce similar conditions among recipients of financial support (Cantore et al., 2020).

\section{Concluding Remarks}

In general, not all companies were affected to the same degree or in the same way by the pandemic. Thus, the effects vary from country to country among industries and companies to different extents. The problems of industries and businesses vary by type of industry/company. Therefore, the political reactions and measures implemented by each government to support their businesses to recover should account for these differences.

Governments around the world and the international community have worked to alleviate the immediate effects of the pandemic crisis. This was done mainly by developing countries. Of course, the countries mentioned above in the analysis of the surveys conducted are no exception. The fact that the media are less likely to receive government support and thus have greater difficulty accessing finances makes it necessary to seek improved policy responses to address the additional problems these companies face due to the pandemic. The combination of policy measures to address the pandemic crisis and its implications for business and industry is an issue that needs to be further explored.

Research results on these issues should generally be monitored. The above analysis, based on recent research data, helps show the absence of a visible strategy and policies to support business in their process of reorientation and restarting. The way in which developing countries' government measures are adapted to operational needs and difficulties affects their prospect of being resilient, inclusive of businesses, and having a sustainable industrialization. Indeed, China, European countries, and the United States have already launched aggressive plans to boost their productivity and business innovation. Developing countries should take advantage of this and widen the asymmetries they already have. 


\section{References}

Abebe, G., Bundervoet, T., \& Wieser, C. (2020). Monitoring COVID-19 Impacts on Firms in Ethiopia: Results from a High-Frequency Phone Survey of Firms. Washington, DC: World Bank. Retrieved 15 May 2020, from https://openknowledge.worldbank.org/handle/10986/33766

Bulman, T., \& Koirala, S. (2020). The OECD COVID-19 Policy Tracker: What are governments doing to deal with the COVID-19 pandemic?. Ecoscope, an Economic Lens on Policies for Growth and Wellbeing. Retrieved 15 May

from https://oecdecoscope.blog/2020/05/15/the-oecd-covid-19-policy-tracker-what-are-governments-doing-to-deal-w ith-the-covid-19-pandemic/

Cantore, N., Hartwich, F., Lavopa, A., Haverkamp, K., Laplane, A., \& Roddousakis, N. (2020). Coronavirus: the economic impact - 10 July 2020. A health pandemic or a pandemic for the economy? April 2020 and some early evidence of firms' perceptions. Policy, Research and Statistics Department, UNIDO. Retrieved 10 July 2020, from https://www.unido.org/stories/coronavirus-economic-impact-10-july-2020

Chatzitheodoridis, F., \& Kontogeorgos, A. (2020). Exploring of a Small-Scale Tourism Product under Economic Instability: the Case of a Greek Rural Border Area. Economies, 8(3), 52. https://doi.org/10.3390/economies8030052

Cohen, J. (2020, 11 January). Chinese researchers reveal draft genome of virus implicated in Wuhan pneumonia $\begin{array}{llllll}\text { outbreak. } & \text { Science. } & \text { Retrieved } & 3 & \text { February } & \text { 2020, from }\end{array}$ https://www.sciencemag.org/news/2020/01/chinese-researchers-reveal-draft-genome-virus-implicated-wuhan-p neumonia-outbreak

Fehr, A. R., \& Perlman, S. (2015). Coronaviruses: an overview of their replication and pathogenesis. In Maier, H. J., Bickerton, E., \& Britton, P (Eds.), Coronaviruses. Methods in Molecular Biology (1282, pp. 1-23). Springer.

Hernández, J. C. (2020, 14 March). As China Cracks Down on Coronavirus Coverage, Journalists Fight Back. The New York $\quad$ Times. $\quad$ Retrieved $14 \quad$ March 2020, from https://www.nytimes.com/2020/03/14/business/media/coronavirus-china-journalists.html

International Institute for Sustainable Development (IISD). (2020). COVID-19 Stimulus Spending for Green Construction Means Building Back Better. Retrieved 21 April 2020, from https://sdg.iisd.org/commentary/guest-articles/covid-19-stimulus-spending-for-green-construction-means-buildi ng-back-better/

International Monetary Fund. (2020). IMF Data Mapper. Plot and compare country data. Retrieved 27 July 2020, from https://www.imf.org/external/index.htm

Javier, C. H. (2020). As China Cracks Down on Coronavirus Coverage, Journalists Fight Back. The New York Times. $\begin{array}{lllll}\text { Retrieved } & 6 & \text { April } & 2020, & \text { from }\end{array}$ https://www.nytimes.com/2020/03/14/business/media/coronavirus-china-journalists.html

Jones, L., Palumbo, D., \& Brown, D. (2020). Coronavirus: A visual guide to the economic impact. BBC. Retrieved 30 June 2020, from https://www.bbc.com/news/business-51706225

Khan, N. (2020, 9 January). New Virus Discovered by Chinese Scientists Investigating Pneumonia Outbreak. The Wall Street Journal. Retrieved from https://www.wsj.com/articles/new-virus-discovered-by-chinese-scientists-investigating-pneumonia-outbreak-11 578485668

Lim, Y. X., Yan Ling, N. G., Tam, J. P., \& Liu, D. X. (2016, July 25). Human Coronaviruses: A Review of Virus-Host Interactions. Diseases, 4(3), 26.

LinkedIn Corporation. (2020). Workforce Report. United States: Economic Graph Team. Retrieved 2 April 2020, from https://economicgraph.linkedin.com/resources/linkedin-workforce-report-april-2020

Mazzucato, M., \& Andreoni, A. (2020). No More Free-Lunch Bailouts. Project Syndicate. Retrieved 25 June 2020, from

https://www.project-syndicate.org/commentary/conditional-bailouts-of-private-companies-2020-crisis-by-maria na-mazzucato-and-antonio-andreoni-2020-06?barrier=accesspaylog

Myers, S. L. (10 March 2020). Xi Goes to Wuhan, Coronavirus Epicenter, in Show of Confidence. The New York $\begin{array}{lllll}\text { Times. } & \text { Retrieved } & 18 & \text { March } & \text { 2020, from }\end{array}$ 
https://www.nytimes.com/2020/03/10/world/asia/coronavirus-china-xi-jinping.html

Myers, S. L., \& Rubin, A. J. (2020, March 18). Its Coronavirus Cases Dwindling, China Turns Focus Outward. The New York Times. $\quad$ Retrieved $31 \quad$ March 2020, from https://www.nytimes.com/2020/03/18/world/asia/coronavirus-china-aid.html

Noy, I., Doan, N., Ferrarini, B., \& Park, D. (2020a). Measuring the Economic Risk of COVID-19. Covid Economics, 3, 103-118.

OECD. (2020). Evaluating the initial impact of COVID-19 containent measures on economic activity. Retrieved 10 June 2020, from https://read.oecd-ilibrary.org/view/?ref=126_126496-evgsi2gmqj\&title=Evaluating_the_initial_impact_of_CO VID-9_containment_measures_on_economic_activity

Organisation for Economic Co- Operation and Development (OECD). (2020). Short-Term Labour Market Statistics: Monthly Unemployment Levels. Retrieved from https://stats.oecd.org/Index.aspx?QueryId=36325

Petchenik, I. (2020). The latest coronavirus airline and aviation industry news. Latest news articles. Flight Radar flight monitoring service 24. Retrieved 1 May 2020, from https://www.flightradar24.com/blog/latest-coronavirus-airline-and-aviation-industry-news/

Retrieved from https://economicgraph.linkedin.com/resources/linkedin-workforce-report-april-2020

Retrieved from https://www.bbc.co.uk/news/business-52917118

Retrieved

from https://www.bloomberg.com/news/articles/2020-02-22/china-s-xi-writes-thank-you-letter-to-bill-gates-for-virus -help

Retrieved from https://www.imf.org/external/index.htm

Sobey, R. (2020, 31 March). Chinese government lying about coronavirus could impact U.S. business ties: Experts. Boston Herald. $\quad$ Retrieved 6 April 2020 , from https://www.bostonherald.com/2020/03/31/chinese-government-lying-about-coronavirus-could-impact-u-s-busi ness-ties-experts/

World Health Organization (WHO). (2015). Middle East respiratory syndrome coronavirus (MERS-CoV). World Health Organization. $\quad$ Retrieved 6 April https://www.who.int/en/news-room/fact-sheets/detail/middle-east-respiratory-syndrome-coronavirus-(mers-cov)

World Health Organization (WHO). (2020a). WHO Director-General's opening remarks at the media briefing on COVID-19. World Health Organization (WHO) (Press release). Retrieved 6 April 2020, from https://www.who.int/dg/speeches/detail/who-director-general-s-opening-remarks-at-the-media-briefing-on-covi d-19---11-march-2020

World Health Organization (WHO). (2020b). Naming the coronavirus disease (COVID-19) and the virus that causes it. World Health Organization (WHO). Retrieved 6 April 2020, from https://www.who.int/emergencies/diseases/novel-coronavirus-2019/technical-guidance/naming-the-coronavirusdisease-(covid-2019)-and-the-virus-that-causes-it

World Health Organization (WHO). (2020c, 11 February). COVID-19: New coronavirus given name by World Health Organization. CanWest Global. Global News. Retrieved from https://www.youtube.com/watch?v=GKymX9j_j9Q

Yella, H. M. (2020). COVID-19 is now a pandemic: What next? Medical News Today. Retrieved 12 March 2020, from https://www.medicalnewstoday.com/articles/covid-19-is-now-a-pandemic-what-next

\section{Copyrights}

Copyright for this article is retained by the author(s), with first publication rights granted to the journal.

This is an open-access article distributed under the terms and conditions of the Creative Commons Attribution license (http://creativecommons.org/licenses/by/4.0/). 